\title{
Comparison of climatic trends and variability among glacierized environments in the Western Himalayas
}

\author{
A. P. Dimri ${ }^{1}$ • W. W. Immerzeel ${ }^{2}$ - N. Salzmann ${ }^{3}$ - R. J. Thayyen ${ }^{4}$
}

\begin{abstract}
The climate and hydrology of the Western Himalayas is complex and a function of snow and glacier melt, land use, topography, and Indian summer and winter monsoon dynamics. Improving our knowledge about these processes is important from societal and agricultural points of view. In this study, an observational analysis is carried out to assess the changing climatic trends and the associated interannual variability in winter temperature and precipitation at three glacierized regions of Western Himalayas having distinctly different sub-regional characteristics. In situ observations of 23 years (1985-2007) are used. These observations are passed through rigorous statistical quality control checks. Results show higher interannual variability with increasing temperature trends in the glacierized regions of the Siachen (Karakoram Range) and Chotasigri (Great Himalayan Range). Karakoram Range has higher warming trends than the Great Himalayan Range. In case of precipitation, an overall decrease in precipitation is observed with contrasting trends in the last decade. Nino3.4 index is positively correlated with winter precipitation with similar interannual variability. In addition, at Siachen temperature and precipitation show strong negative correlation, and precipitation to spell length correlation is opposite at Siachen and Chotasigri.
\end{abstract}

A. P. Dimri

apdimri@hotmail.com

1 School of Environmental Sciences, Jawaharlal Nehru University, New Delhi, India

2 Department of Geosciences, Utrecht University, Utrecht, Netherlands

3 Department of Geography, University of Fribourg, Fribourg, Switzerland

4 National Institute of Hydrology, Uttrakhand, Roorkee, India

\section{Introduction}

The Western Himalayas is characterized by various mountain ranges and glacier systems (Dyurgerov and Meier 2005; Kaul and Puri 1999) that are sensitive to changing climate (Houghton et al. 2001; Mool et al. 2001a, b; Barnett et al. 2005; Solomon et al. 2007). Various researchers studied interannual variability and related changes in temperature and precipitation over the Himalayas (Dimri and Dash 2010; Bhutiyani et al. 2007, 2010; Basistha et al. 2009; Shrestha et al. 1999,2000; Baidya et al. 2008 and Jhajharia and Singh 2010) and also over isolated and individual glaciers (Upadhyay 2009; Ganjoo and Koul 2009; Dimri and Dash 2010; Wagnon et al. 2007; Berthier et al. 2007; Dobhal et al. 1995; Kumar et al. 2008; Naithani et al. 2001; Chaujar 2009 and Kulkarni et al. 2004, 2007). In recent decades, glacier and snow extent changes are reported from different parts of the Himalayas, suggesting glacier volume depletion from 28 to 16\% (Hewitt 2005; Nie et al. 2010). Further, soot deposition leading to warming of snow and glacier (Ramanathan et al. 2007; Sateesh et al. 2008); snow cover decreases during 1990-2001 by 16\% (Menon et al., 2010) and Gurung et al. (2011) reported decreasing trends in winter snow cover. In addition, Western Himalayas is characterized by high interannual climate variability (Dimri 2005, 2006; Immerzeel et al. 2009, Immerzeel et al. 2010) and different zonal and meridional mass transport mechanisms (Dimri 2007; Bookhagen and Burbank 2010).

Many studies have looked into various physical and climatic processes over and across the Himalayas. However, limited comparative studies across glacierized regions, situated in different climatic sub-regions and their responses to the climate change, based on field observations are available. Most of the above studies of glacierized catchments are based on mass balance, modeling, or remote sensing techniques. In the 


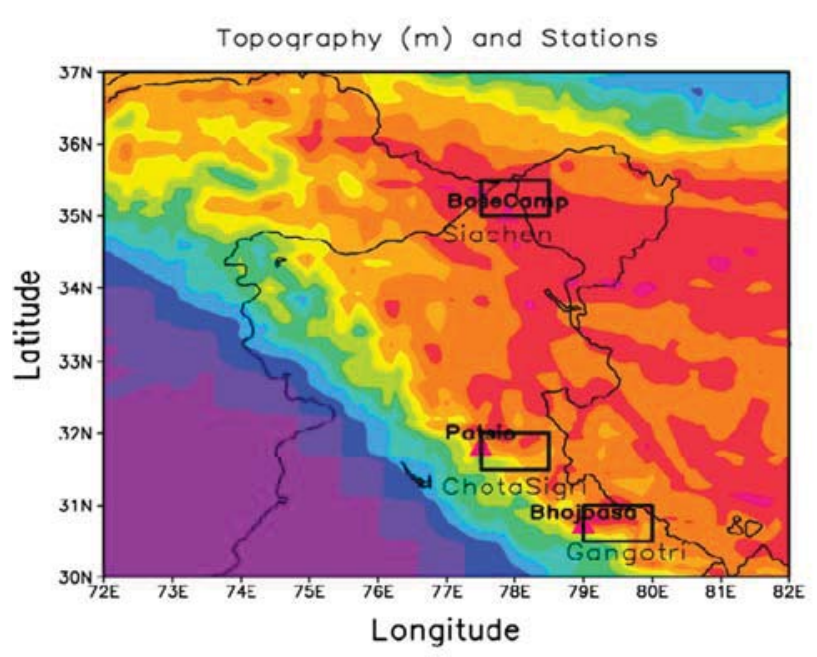

Fig. 1 Topographical (m) map of Western Himalayas marked with stations and glacierized regions along with topo sheet map of Siachen glacier (upper right hand panel), Chotasigri glacier (middle right hand panel) and

present study, we compared three glacierized regions situated in different climatic sub-regimes of Western Himalayas where long-time observations are also available. Temperature trends, precipitation trends, and its spell lengths and correlations with global atmospheric modes are calculated using methods described in Dimri and Dash $(2010,2012)$. Associated changes and interannual variabilities are presented and discussed here. The three stations considered in the study are the Siachen glacier (Karakoram), the Chotasigri glacier (Greater Himalayas), and the Gangotri glacier (Greater Himalayas). Siachen is situated in the non-monsoonal region; Chotasigri is situated in the cusp of non-monsoonal and monsoonal region and Gangotri is situated in the monsoonal region. These distinct characteristics will lead to different climatic responses at local to regional to global scale. In addition, importantly, these regions are chosen as long-term winter temperature, and precipitation records are available at their snout position (Fig. 1 and Table 1). Also, it is imperative to mention here that the Himalayan regions are less monitored, and hence, such data and corresponding analysis will add new dimensions to the existing researches and findings. Figure 1 shows the complex topographic region of the Western Himalayas

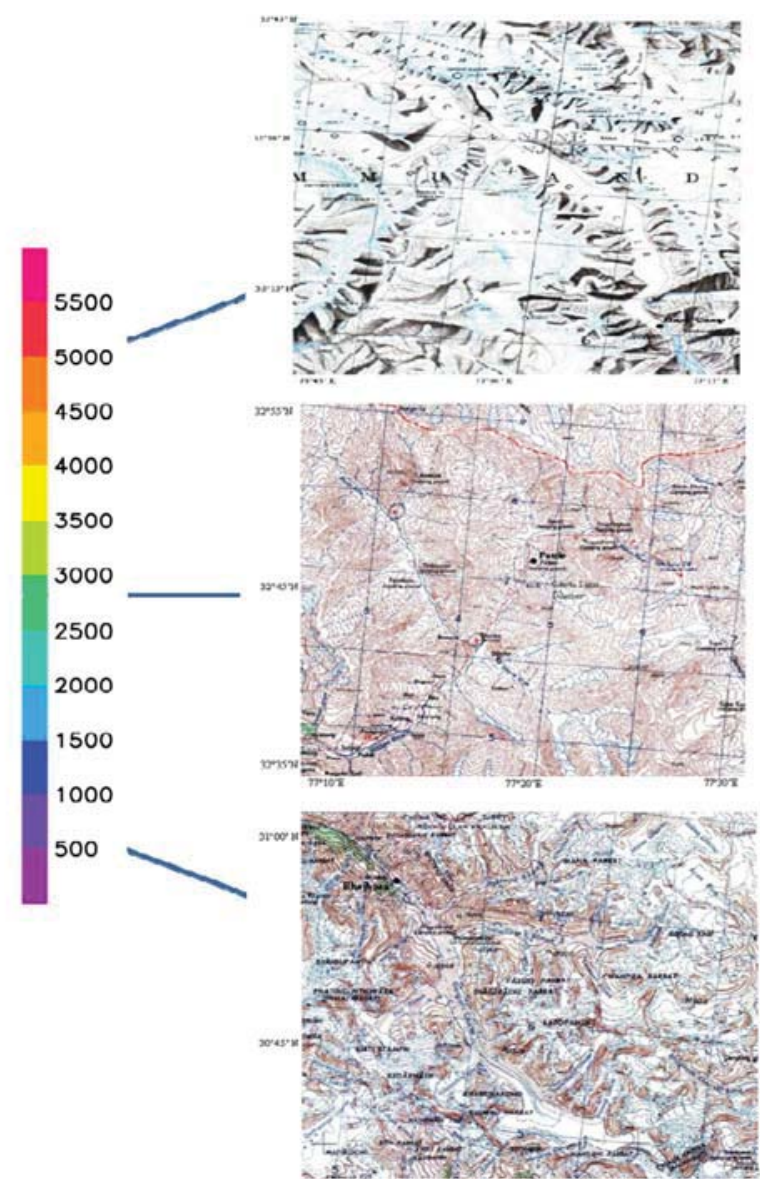

Gangotri glacier (lower right hand panel). (Source: University of Texas Libraries, The University of Texas at Austin: http://www.lib.utexas.edu/ maps/ams/india/)

along with corresponding topo sheets of these three glacierized regions in the right hand panels, respectively.

\section{Data and methodology}

\subsection{Data and associated uncertainties}

Long-term observations of maximum, minimum, daily temperature, and precipitation during winter (December, January, and February: DJF) at Siachen, Chotasigri, and Gangotri of the Snow of Avalanche Study Establishment (SASE), Chandigarh, India are used. Available data from 1984(D)$85(\mathrm{JF})$ to $2006(\mathrm{D})-07(\mathrm{JF})$ at Siachen and Chotasigri and from 1999(D)-2000(JF) to 2006(D)-07(JF) at Gangotri are used in the present analysis (Table 1). To assess the correlation with global atmospheric modes, the winter Nino3.4 index is considered (http://www.esrl.noaa.gov/psd/gcos_wgsp/ Timeseries/Data/nino34.long.data).These observations are taken at synoptic hours as per the World Meteorological Organization (WMO) standards. In the time series, observation year is dropped if more than $20 \%$ of daily data are 
Table 1 Stations at snout locations, elevations and data length

\begin{tabular}{lllll}
\hline Station & Latitude & Longitude & Altitude & Data length \\
\hline Basecamp (Siachen Glacier) & $35^{\circ} 11^{\prime} 49^{\prime \prime} \mathrm{N}$ & $77^{\circ} 12^{\prime} 28^{\prime \prime} \mathrm{E}$ & $3570 \mathrm{~m}$ & $1984-85$ to 2006-2007 \\
Patsio (Chotasigri Glacier) & $32^{\circ} 45^{\prime} 17^{\prime \prime} \mathrm{N}$ & $77^{\circ} 15^{\prime} 42^{\prime \prime} \mathrm{E}$ & $3800 \mathrm{~m}$ & $1984-85$ to 2006-2007 \\
Bhojbasa (Gangotri Glacier) & $30^{\circ} 55^{\prime} 00^{\prime \prime} \mathrm{N}$ & $79^{\circ} 00^{\prime} 00^{\prime \prime} \mathrm{E}$ & $3792 \mathrm{~m}$ & $1999-2000$ to 2006-2007 \\
\hline
\end{tabular}

missing. After checking the availability of the data, stationarity and inhomogeneity of the time series is also taken care off. The major causes of inhomogeneity include changes in instrument exposure, observing time, and co-located station observations that are taken together to produce a longer time series. Temporal inhomogeneity due to either station situated in the windward side of the mountain or for station where winds affect the precipitation pattern is corrected (Liu and Sun 1995). Inhomogeneity due to relocation and due to changes in observing procedures is addressed by using a technique based on regression models and surrounding stations (Vincent 1998). Overall, stringent quality control (Mohanty and Dimri 2004), temporal and spatial inhomogeneity (Liu and Sun 1995, Vincent 1998) checks in the context of missing data, errors, repetivity, and data gaps are employed in the data time series. After these checks, data time series are prepared for analyzing the interannual variability and associated changes.

It is important to mention here that observations in the mountainous regions are very critical in representing the region around. In Indian Himalayas, lesser density of gauge stations in valley tops and higher density in valley floors need careful assumption as they are the representation of the subregions. There are various physical processes that will be occurring viz., katabatic-anabatic wind flow, albedo measures, snow drift, and accumulation. Moisture-temperature interactions over monsoonal and non-monsoonal region will respectively have different manifestations and impacts on localized circulation. Apart from these, observations and its network need to be considered carefully in the mountains. Intensive observational network, though desired, is not economically viable over the mountainous region and therefore, wider network is more desirable. However, for specific studies at basinglacier scale singular observation is prevalent. There are many non-linear and complex issues that occur over these regions, which need to be understood within the realms and the aims of the scientific questions posed.

Taking all these factors into account, the temperature values (dry bulb at 0300UTC and 1200UTC of previous day, dry bulb at 0300UTC of current day, maximum and minimum temperature) are averaged for generating the final time series. Temperature records show highly variable diurnal cycle during winter due to sun aspect and land use/cover of the observatories. Also, meso/micro scale circulation generated due to the local topography and their interaction with large scale eastward moving WDs make temperature regimes highly complex. Thus, five temperature records are considered with a view to remove biases due to above reasons. Finally, the above corrected time series are normalized. Standardized time series of monthly and seasonal anomalies are also examined. It may be mentioned here that anomalies are calculated by subtracting the respective mean values and then dividing those by the respective standard deviations as followed by Wilks (1995).

It may be noted that the Western Himalayas receives precipitation in the form of snow during the winter months of December to February. Also, sometimes precipitation is in the form of sleet. Thus, a large uncertainty is implicit in obtaining equivalent liquid water content based on the density factor of snow as followed by Dickinson et al. (1993). Further, geographical location of the station depends on its elevation point. Finally, the observed snow depth at a station is strongly affected by processes such as snowdrift and snow sheltering by upwind obstacles. These are the issues which need careful examination.

In case of precipitation, stringent quality control checks as mentioned in Section 2.1 are employed. In the present study, snow records (in $\mathrm{cm}$ ) are converted into water equivalent (in $\mathrm{mm}$ ) by multiplying it with the corresponding densities measured at the time of observations only. Also, time series are normalized, and anomalies are computed as in the case of temperature.

\subsection{Methodology}

For temperature, five temperature observations viz., dry bulb at 0300UTC and 1200UTC of previous day, dry bulb at 0300UTC, and maximum and minimum temperature of current day, are averaged to remove biases due to land use (Dimri 2009) and topography (Dimri 2004). Subsequently anomaly calculations are performed (Wilks 1995). Precipitation forming mechanisms and processes over the glaciated region in the mountains is complex (Dimri 2004). In addition, topographic positioning of the stations determines processes such as snowdrift and snow sheltering, and thus the precipitation is leading to subsequent snow depth. In addition, liquid-to-solid precipitation determination is still a big challenge over the mountainous regions. These processes added together bring in huge uncertainty in estimating snow cover, snow amount, and its density. Therefore, conversion of snow amount to water equivalent using the snow density remains very uncertain (Dickinson et al. 1993). However, in the present study, snow records (in $\mathrm{cm}$ ) are converted into water equivalent (in $\mathrm{mm}$ ) by 
Table 2 Definition of temperature and precipitation indices used in the study

\begin{tabular}{|c|c|c|}
\hline Temperature and precipitation indices & Definition & Units \\
\hline Warm days & $\%$ age days with $T_{\max }>90$ th percentile & Day \\
\hline Warm nights & $\%$ age days with $T_{\min }>90$ th percentile & Day \\
\hline Cold days & $\%$ age days with $T_{\max }<10$ th percentile & Day \\
\hline Cold nights & $\%$ age days with $T_{\min }<10$ th percentile & Day \\
\hline Mean climatological precipitation & $\begin{array}{l}\text { Seasonal (DJF) total precipitation/number } \\
\text { of days with } P>\text { trace }\end{array}$ & $\mathrm{mm}_{\text {day }}{ }^{-1}$ \\
\hline Heavy precipitation days & Number of days precipitation $\geq 10 \mathrm{~mm}$ & Day \\
\hline Maximum number of consecutive dry days of $P$ & $\begin{array}{l}\text { Maximum number of consecutive dry days } \\
\text { (trace days are excluded) }\end{array}$ & Day \\
\hline Maximum number of consecutive wet days of $P$ & Maximum number of consecutive wet days & day \\
\hline
\end{tabular}

$T_{\max }$ and $T_{\min }$ are daily maximum and minimum temperatures, respectively. $P$ denotes total precipitation. Precipitation is considered as trace if amount in $\leq 1 \mathrm{~mm} / \mathrm{d}$ multiplying it with its corresponding densities taken at the same time of observations. These time series are quality controlled as mentioned in the preceding subsection. Then, these temperature and precipitation time series are normalized and anomalies are computed.

Set of various temperature and precipitation indices are computed using European Commission funded project based Statistical Dynamical Downscaling of Extremes (STARDEX) Diagnostics Extremes Indices Software (available at http:// www.cru.uea.ac.uk/projects/stardex/). Homogenized daily maximum, minimum, and dry bulb temperatures and precipitation time series are used for computing temperature and precipitation indices, respectively. Data of the year is not included in the percentile calculation based indices if more than $20 \%$ of the daily data are missing in those years. Normalized seasonal (DJF) temperature and anomalies time series are calculated as $\frac{1}{\mathrm{SD}}\left(\frac{x_{i}-\bar{x}}{\bar{x}}\right)$ and $\left(\frac{x_{i}-\bar{x}}{S D}\right)$, respectively (where $\mathrm{SD}$ is standard deviation; $x_{i}$ is the actual time series, and $\bar{x}$ is the mean of that time series). Three group resistant line method (Hoaglin et al. 1983) is used to compute all the trends in the above indices. Statistical significance is determined using the Kendall tau test (Press et al. 1986). Here, a trend is defined "significant," if it has at least 95\% significance using this test. In addition, spell length for winter is computed as $\left(r=P_{\mathrm{ww}}-(1\right.$ $\left.-P_{\mathrm{dd}}\right)$ ), where $P_{\mathrm{ww}}$ corresponds to the ratio of consecutive wet days to total wet days, and $P_{\mathrm{dd}}$ corresponds to ratio of consecutive dry days to total dry days in winter.

\section{Results and discussion}

In the present study, four temperature indices (warm eventswarm days, warm nights; cold events-cold days, cold nights) and four precipitation indices (precipitation type, frequency, intensity, and extremes) are analyzed. Definitions of these temperature and precipitation indices are given in Table 2. These main calculated indices represent either above the 90th or below the 10th percentile level. These indices are selected, firstly, to analyze basic trends/changes for having focused comprehension, and secondly, since these indices are inter-correlated to a larger degree, hence can provide concerted opinion. It will provide important input for assessing glacier, associated snow melt, discharge in associated river basins, etc.

The average winter temperature for the periods measured is $-9.3{ }^{\circ} \mathrm{C}$ at Siachen, $-6.9{ }^{\circ} \mathrm{C}$ at Chotasigri, and $-4.4{ }^{\circ} \mathrm{C}$ at Gangotri. It is interesting to note that Siachen being at the lowest elevation (Fig. 2) has the lowest temperature as compared to other two stations which are at higher elevations. The standard deviations are almost in the same range for all the three areas $\left(3.4{ }^{\circ} \mathrm{C}\right.$ (Siachen), $3.6{ }^{\circ} \mathrm{C}$ (Chotasigri), and $3.1{ }^{\circ} \mathrm{C}$ (Gangotri)). Figure 2 shows that in recent years, the temperature is frequently higher than 1 standard deviation (SD) above the average. Siachen particularly shows increased number of days above +1 SD in the last 10 years. There are hardly any days when the temperature is below $-1 \mathrm{SD}$ in the last 10 years. This shift towards a higher number of days above $+1 \mathrm{SD}$ is much stronger in the Siachen region (in the Karakoram Range) than in the Chotasigri and Gangotri regions (in the Great Himalayan Range). The IPCC (2007) reported that mountain ranges and their downstream areas will be particularly vulnerable to these changes. Temperature increase is more in higher elevations than lower elevations in the mountainous region (Bradley et al. 2006). Here, we confirm these findings but we also suggest that Siachen being at higher latitude but lower elevation is showing stronger warming trends than the other two glacier systems at lower latitude but higher elevation. It suggests that mountain areas exhibit a large spatial variation in sub-climate zones due to large differences in altitude over small horizontal distances (Beniston et al. 1997), and permanent changes in snow cover may also partly explain differences in the identified trends (Dimri and Dash 2010). 


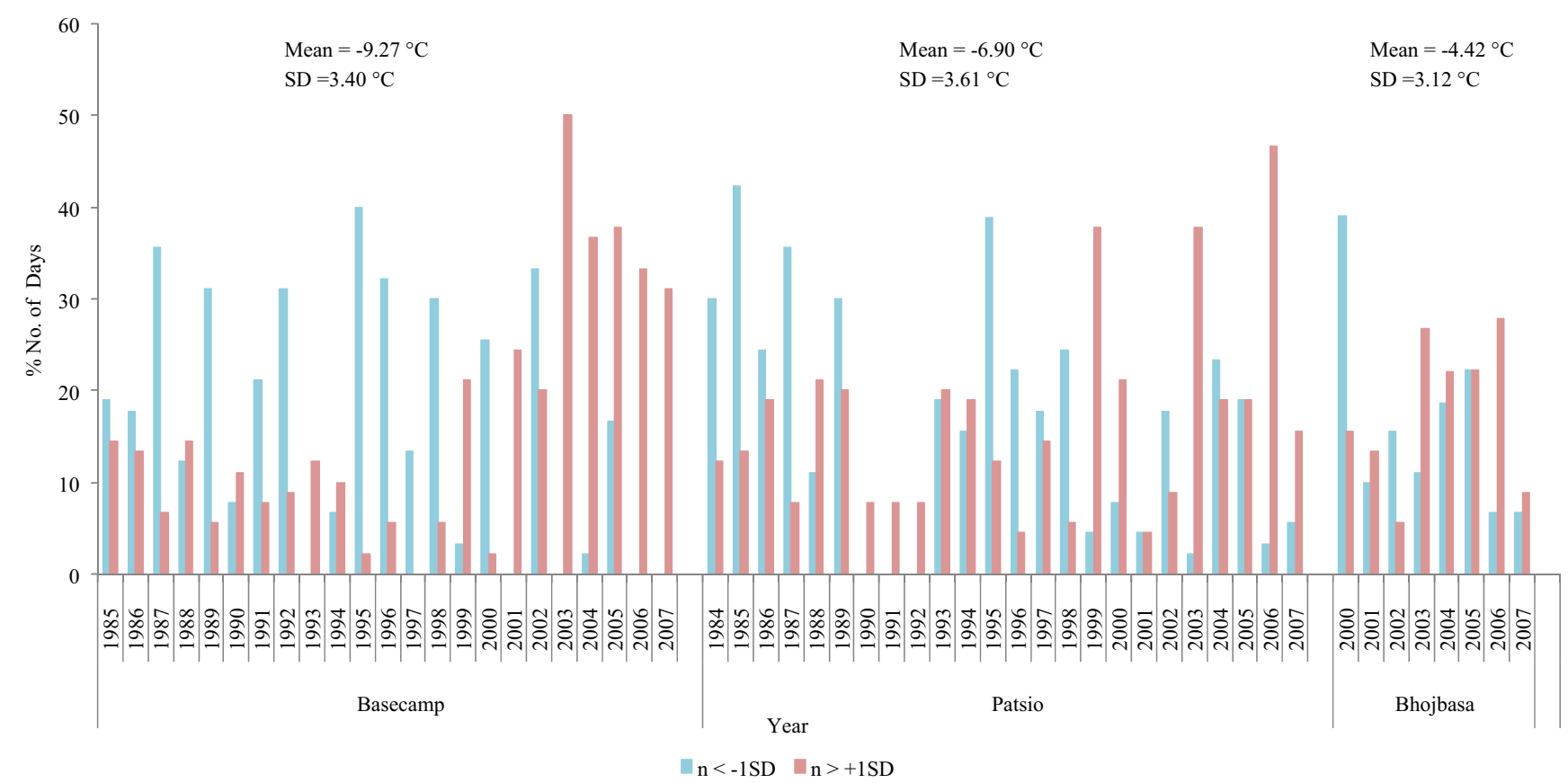

Fig. 2 Distribution of number of percentage days above and below 1 SD at Siachen, Chotasigri, and Gangotri

The normalized temperature anomalous time series with corresponding linear trends at Siachen, Chotasigri, and Gangotri is presented in Fig. 3. It shows strong significant (99\%) positive trends at Siachen $\left(0.09{ }^{\circ} \mathrm{C} /\right.$ year $)$ and Chotasigri $\left(0.06^{\circ} \mathrm{C} /\right.$ year $)$. Comparisons during the common period (2000-2007) show that the winter warming over the Karakoram Range had not only significantly increased over the last 8 years but is also higher than that over the Great Himalayan Range. These findings are also similar across the Himalayan mountain ranges. Immerzeel et al. (2009) have shown strongest warming in winter and weakest in summer, and these warming trends are stronger than the global and Northern Hemispheric winter (IPCC2007). Moreover, Immerzeel et al. (2009) underlined the relation between an increase in temperature with respect to the elevation $\left(0.028{ }^{\circ} \mathrm{C} /\right.$ year at $2000 \mathrm{~m}$ to $0.043{ }^{\circ} \mathrm{C} /$ year at $\left.5000 \mathrm{~m}\right)$.
These facts are also suggested by Bradley et al. (2006) for the Andes Mountains. Giorgi et al. (1997) argued that higher temperature increases over high-altitude areas may be caused by a decrease in surface albedo resulting from the melting of snow and ice. As Dahe et al. (2006) show different results for a region in western China, detailed mechanisms underlying this phenomenon warrant further studies on a regional basis.

The temperature indices pertaining to warm and cold events are assessed and presented with corresponding trends and $p$ values in Table 3. Significant positive trends in the number of warm days ( $T_{\max }$ above the 90th percentile) are observed at Siachen (0.0122 day/year) and Chotasigri (0.0121 day/year). The trends are more significant at Siachen (in the Karakoram Range), than at Chotasigri (in the Great Himalayan Range). The warm nights ( $T_{\min }$ is above the 90th percentile) are also found to be increasing though not
Fig. 3 Comparison of seasonal winter temperatures anomaly $\left({ }^{\circ} \mathrm{C}\right)$ with linear trends (TBc, TP, and TB corresponds to temperature anomaly at Siachen, Chotasigri, and Gangotri, respectively)
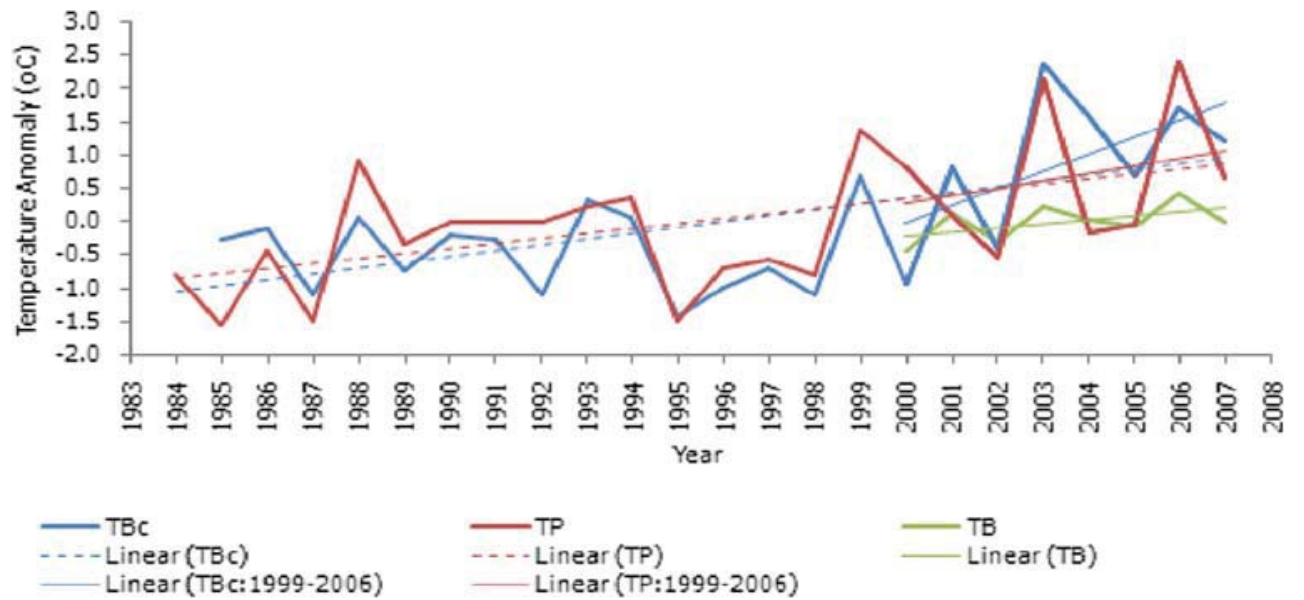
Table 3 Trends and $p$ values for temperature and precipitation indices

\begin{tabular}{|c|c|c|c|c|c|c|}
\hline \multirow[t]{2}{*}{ Temperature and precipitation indices } & \multicolumn{2}{|l|}{ Siachen } & \multicolumn{2}{|l|}{ Chotasigri } & \multicolumn{2}{|l|}{ Gangotri } \\
\hline & Trend & $p$ (trend) & Trend & $p$ (trend) & Trend & $p$ (trend) \\
\hline Warm days (day/year) & 0.0122 & 0.0384 & 0.0121 & 0.002 & 0.011 & 0.523 \\
\hline Warm nights (day/year) & 0.0084 & 0.6394 & 0.0021 & 0.8516 & 0.0073 & 0.864 \\
\hline Cold days (day/year) & 0.0065 & 0.5214 & -0.0058 & 0.1711 & 0.012 & 0.423 \\
\hline Cold nights (day/year) & 0.0109 & 0.0017 & -0.0011 & 0.6469 & 0.0011 & 0.732 \\
\hline $\begin{array}{l}\text { Mean climatological precipitation } \\
(\mathrm{mm} / \text { day/year })\end{array}$ & 0.0297 & 0.1578 & -0.0398 & 0.4897 & -0.0379 & 0.0216 \\
\hline Heavy precipitation days (day/year) & 0.3893 & 0.2727 & 0.0244 & 0.5541 & 0.0021 & 0.793 \\
\hline $\begin{array}{l}\text { Maximum number of consecutive dry } \\
\text { days (day/year) }\end{array}$ & -0.0102 & 0.8364 & 0.4929 & 0.2272 & 0.037 & 0.12 \\
\hline $\begin{array}{l}\text { Maximum number of consecutive wet } \\
\text { days (day/year) }\end{array}$ & 1.2246 & 0.465 & -1.0691 & 0.053 & -0.0212 & 0.783 \\
\hline
\end{tabular}

Italic values are significant at $p<0.05$ significant. In case of cold events (cold days and cold nights), contrasting results at Siachen and Chotasigri are seen. There is a decrease in cold days ( $T_{\max }$ below the 90th percentile) at Chotasigri and an increase at Siachen. A significant increase in cold nights ( $T_{\min }$ is below the 90th percentile) is observed at Siachen (0.0109 day/year).

Average winter seasonal precipitation anomalies are presented in Fig. 4a. The figure shows a similar amount of excess and deficit precipitation years at Siachen and Chotasigri in 23 years. From 2000 onwards, deficit precipitation years at Siachen and Chotasigri are dominant, which suggest a decrease in precipitation. In addition, excess precipitation years
Fig. 4 a Comparison of seasonal winter precipitation anomaly $(\mathrm{mm} / \mathrm{d})$ at Siachen, Chotasigri, and Gangotri. b Linear trends (PBc, $\mathrm{PP}$, and $\mathrm{PB}$ corresponds to precipitation anomaly at Siachen, Chotasigri, and Gangotri, respectively) with Nino3.4 index (on right hand vertical axis) are observed during the 1990s decade both at Siachen and Chotasigri. Comparisons of the overlapping period (20002007) show that Gangotri has a higher interannual variability than Siachen and Chotasigri. Figure 4a also shows first an increase and then a decrease of precipitation at Siachen; a similar trend, but with a lag and lesser magnitude, is observed at Chotasigri. This extreme spatial variability in precipitation could be due to the interplay of complex terrain with winter weather. The extreme topography, Fig. 1, interacts with large scale westerlies and hence determines the precipitation distribution (Dimri 2004). These winter westerlies during their progression from west to east traverse over cascading mountain

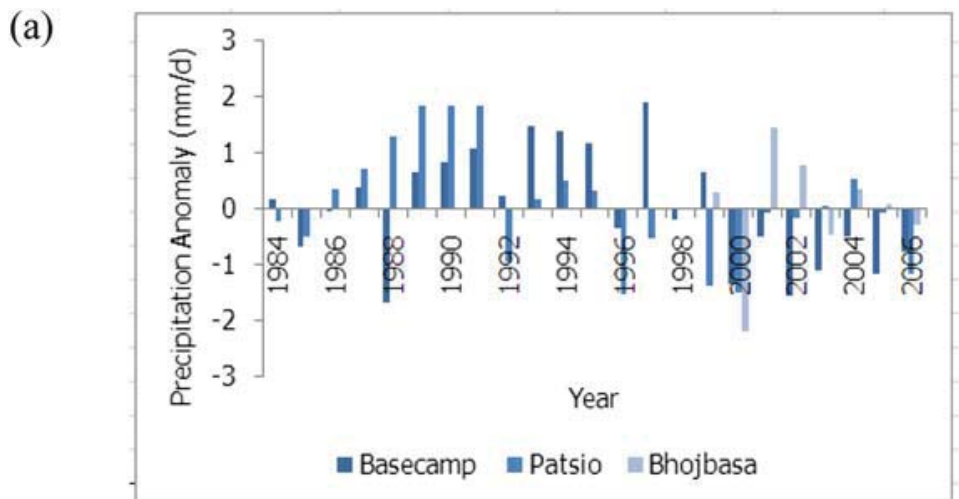

(b)

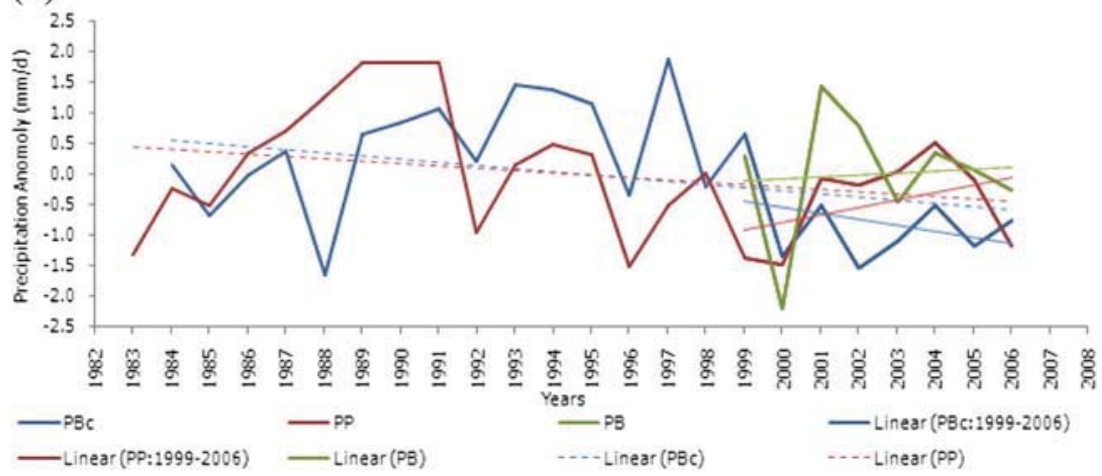


ranges of Western Himalayas. In this process, they shed their moisture, and hence the western side is wetter than the eastern side. This depicts precipitation forming mechanism forcing and role of topographical modulation as well. In addition, type of precipitation is also crucial to determine over the region due to sub-regional climates (since it is beyond the scope of the study, hence, role of Indian summer and winter monsoon is not discussed). Similar results are found by Dahe et al. (2006) in the eastern part of Qinghai-Xizang (Tibet) Plateau where there is a strong year-to-year fluctuation in snow depth. Similar variations in Eurasian snow cover are also reported by Vernekar et al. (1995). Figure 4b shows linear decreasing precipitation trends at Siachen and Chotasigri, but these signals have distinct changes after 2000. Comparison of the overlapping period shows a positive trend here as well. At Siachen and Chotasigri, a continued decreasing trend is observed, which after 2000 is reversed for Chotasigri, but not for Siachen. These contrasts in the last 10 years illustrate the complex variability associated with precipitation in different sub-regions. Though distinct linear changes are discernible, they still need to be seen with a more comprehensive study.

To confirm links with global atmospheric modes, the precipitation variability is correlated with the Nino3.4 index. Positive Pearson product moment correlation coefficients of $0.40,0.21$, and 0.25 are found between precipitation and Nino3.4 index at Siachen, Chotasigri, and Gangotri, respectively. This illustrates that on a larger scale, precipitation distribution over these regions is linked to warming of equatorial Pacific (Dimri 2013). These positive correlations suggest that global factors also play an important role in defining precipitation mechanisms over Western Himalayas. A similar decreasing trend $(-0.34 \%$ per year) is observed over the Tibetan Plateau. Immerzeel et al. (2009) have shown significant negative trends for winter snow cover in the upper Indus basin based on 2000-2008 observations. The present study thus corroborates these findings based on the long-term observations of 23 years. These correlations are thought off to take assessment of larger scale teleconnections, though discussed very briefly here. These correlations are considered to understand relations between winter precipitation variability and warming of equatorial Pacific over non-monsoonal region (Siachen), region in cusp of non-monsoonal and monsoonal region (Chotasigri), and monsoonal region (Gangotri). This sub-regional scale difference in characteristic properties will have different associated mechanisms and fall outs. Hence, these attributes at these sub-regional scales differ in climate and thus will determine the role of large scale forcing, which will be ascertained and confirmed in the future study.

Computed precipitation indices are presented in Table 3. Average winter seasonal precipitation shows contrasting trends at Siachen (positive) and Chotasigri (negative). In case of heavy precipitation days, no significant changes are (a)

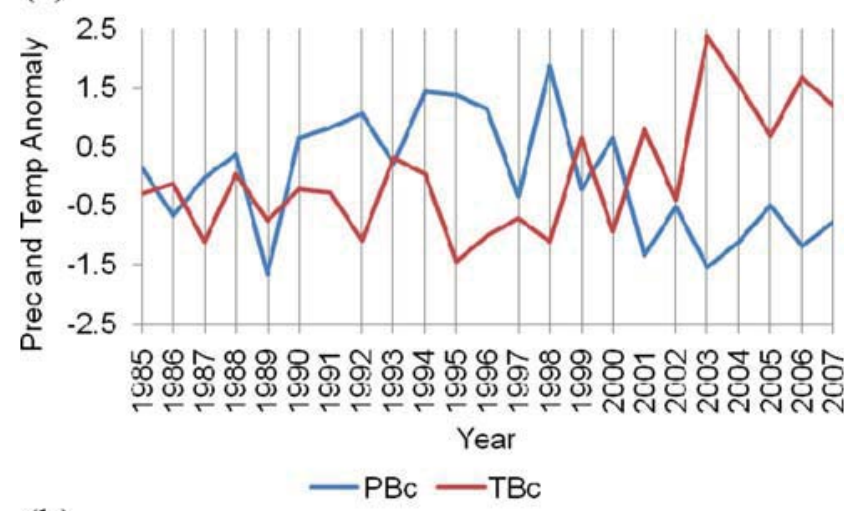

(b)

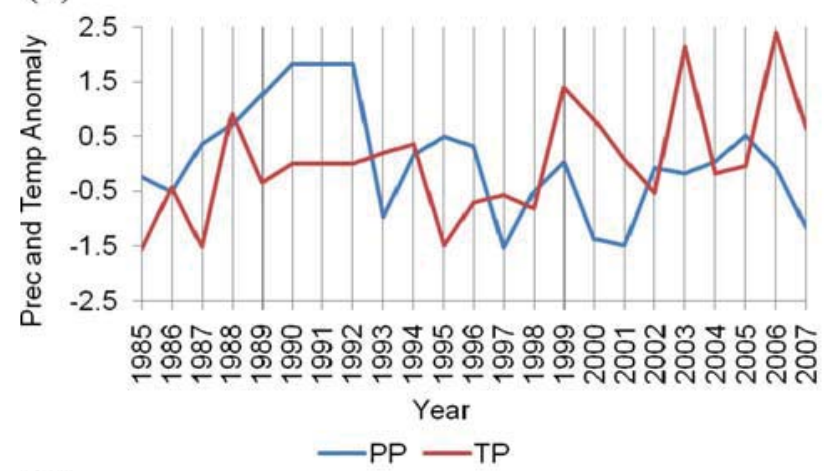

(c)

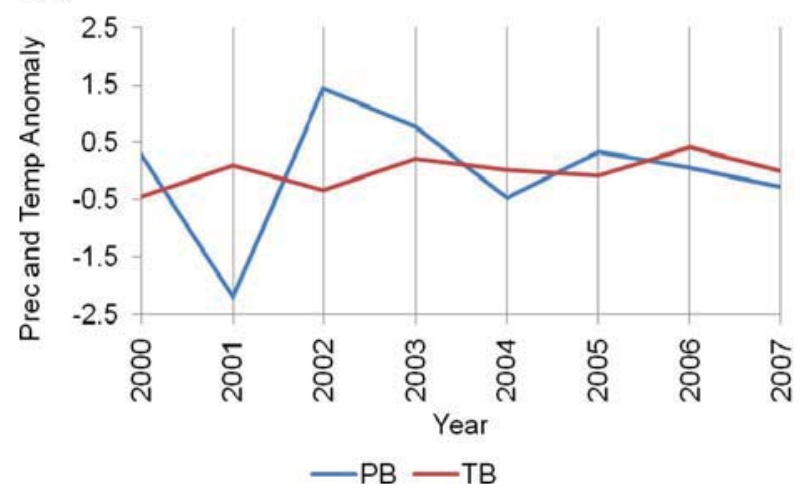

Fig. 5 Precipitation $(\mathrm{mm} / \mathrm{d})$ and temperature $\left({ }^{\circ} \mathrm{C}\right)$ anomaly at (a) Siachen, (b) Chotasigri, and (c) Gangotri

observed. Dry and wet day indices are also computed. The number of consecutive dry days is found to be increasing at Siachen and decreasing at Chotasigri, and the opposite is observed for consecutive wet days. Overall, we conclude that the Siachen region (in the Karakoram Range) and the Chotasigri region (in the Great Himalayan Range) show contrasting precipitation trends.

Further investigation of longterm trends in winter precipitation may provide a startling point for understanding the future behavior of precipitation over the Western Himalayas. Looking into the individual glacier basins, we found interesting relationships between temperature and precipitation, Fig. 5. Results from standardized time series of precipitation 


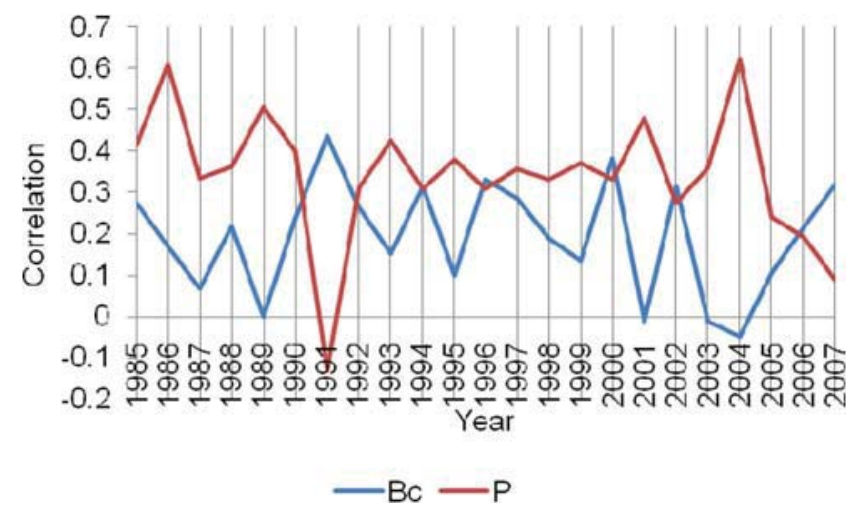

Fig. 6 Correlation with spell length at Siachen and Chotasigri

and temperature anomaly show interesting linkages. In general, they reveal, but not uniform, opposite patterns between temperature and precipitation over the Western Himalayas with positive Pearson product moment correlation coefficient of $-0.67,-0.1$, and -0.32 at Siachen, Chotasigri, and Gangotri, respectively. This intends that an increase in temperature corresponds to a decrease in precipitation and/or vice-versa (Fig. 5). In addition, when the trend is changing, for example at Siachen after 2000 (Fig. 5a), the increasing warming trends are linked to decreasing precipitation trends. The same patterns, although less explicit, are observed at Chotasigri and Gangotri.

Finally, we quantified the relation between precipitation and storm duration by the spell length in Fig. 6. It shows that a long consecutive wet period is linked to higher precipitation at Siachen and the opposite is observed for Chotasigri. It also shows that the correlations at these two stations are opposite to each other. The time scales of the precipitation event do not match and attribute to the synoptic weather events in large scale westerlies (Dimri 2004). They show a significant decreasing trend with $95 \%$ confidence level at both the places.

\section{Conclusions}

The present study provided an overview of winter trends in temperature and precipitation over three Western Himalayan glacierized regions based on field data. All regions show similar increase in warming during winters. On comparison, the warming trend is higher in the Karakoram than in the Great Himalayan Range. Importantly, it is noticed that during the last decade, changes in temperature are higher than the preceding two decades. Variability in temperature is increased and is higher in recent decade than the preceding two decades. Though all the regions show almost similar interannual variability, there are subtle differences in the changes associated with it. It is, however, important to note that recent decade is showing signatures of higher warming rates. In the case of precipitation, similar interannual variability exists in both
Siachen and Chotasigri, with a negative precipitation anomaly during the last 10 years. During the decade of 1990s, increase in precipitation is seen over the regions and this decreases in the subsequent decades. Though, precipitation remains below mean, increased precipitation trend over the Chotasigri glacier region is interestingly discernible. It shows a contrasting subregional behavior of climate variability, which is mainly dependent on moisture-topography-temperature interactions on defining associated precipitation. Precipitation-temperature relationship shows an inverse relation between their trends at every region. Increase in temperature leads to decreased precipitation or vice-versa. This relation justifies the rationale of physical precipitation forming mechanism and will be looked into detail in future studies. Interannual variability in precipitation is linked to the Nino3.4 index over these glacierized regions and stronger signals are found over Siachen. These temperature and precipitation trends are found to be in tune with the global and Northern Hemispheric trends. A further study to understand temperature and precipitation variability and their impact on glacier processes is still needed.

Acknowledgments APD acknowledges Ms. Anila Rambal for providing English edits of the manuscript.

\section{References}

Baidya SK, Shrestha ML, Sheikh MM (2008) Trends in daily climatic extremes of temperature and precipitation in Nepal. J Hydrol Meteorol 5:38-51

Barnett TP, Adam JC, Lettenmaier DP (2005) Potential impact of a warming climate on water availability in snow dominated regions. Nature 438:303-309

Basistha A, Arya DS, Goel NK (2009) Analysis of historical changes in rainfall in the Indian Himalaya. Int J Climatol 29:555-572

Beniston M, Diaz HF, Bradley RS (1997) Climatic change at high elevation sites: an overview. Clim Chang 36:233-251

Berthier E, Arnau Y, Kumar R, Ahmad S, Wagnon P, Chevallier P (2007) Remote sensing estimates of glacier mass balance in the Himachal Pradesh (western Himalaya, India). Remote Sensing Environ 108: 327-338

Bhutiyani MR, Kale VS, Pawar NJ (2007) Long-term trends in maximum, minimum and mean annual air temperatures across the northwestern Himalaya during the twentieth century. Climate Change 85: 159-177

Bhutiyani MR, Kale VS, Pawar NJ (2010) Climate change and the precipitation variations in the northwestern Himalayas:1866-2006. Int J Climatol. https://doi.org/10.1002/joc.1920

Bookhagen B, Burbank DW (2010) Toward a complete Himalaya hydrological budget: spatiotemporal distribution of snowmelt and rainfall and their impact $\mathrm{n}$ river discharge. J Geophys Res 115. https://doi. org/10.1029/2009JF001426

Bradley SB, Vuille M, Diaz HF, Vergar W (2006) Threats to water supplies in the tropical Andes. Science 312:1755-1756

Chaujar RK (2009) Climate change and its impact on the Himalayan glaciers - a case study on the Chorabari glacier, Garhwal Himalaya, India. Curr Sci 96:703-708

Dahe Q, Shiyin L, Peiji L (2006) Snow cover distribution, variability, and response to climate change in western China. J Clim 19:1820-1833 
Dickinson RE, Henderson-Sellers A, and Kennedy PJ (1993) Biospheresatmosphere transfer scheme (BATS) version 1e as coupled to the NCAR Community climate model, NCAR tech. Note NCAR/TN387+STR, 72 pp.

Dimri AP, Dash SK (2010) Winter temperature and precipitation changes in the Siachen Glacier. Curr Sci 98(12):1620-1625

Dimri AP, Dash SK (2012) Wintertime climatic trends in the western Himalayas. Clim Chang 111(3-4):775-800

Dimri AP (2004) Impact of horizontal model resolution and orography on the simulation of a western disturbance and its associated precipitation. Meteorol Appl 11(2):115-127

Dimri AP (2005) The contrasting features of winter circulation during surplus and deficient precipitation over western Himalayas. PAGEOPH 162(11):2215-2237

Dimri AP (2006) Surface and upper air fields during extreme winter precipitation over western Himalayas. PAGEOPH 163(8):1679-1698

Dimri AP (2007) The transport of mass, heat and moisture over western Himalaya during winter season. Theor Appl Climatol 90:49-63

Dimri AP (2009) Impact of subgrid scale scheme on topography and Landuse for better regional scale simulation of meteorological variables over western Himalaya. Clim Dyn 32:565-574

Dimri AP (2013) Interannual variability of Indian winter monsoon over the western Himalayas. Global and Planetray Change (In Press)

Dobhal DP, Kumar S, Mundepi AK (1995) Morphology and glacier dynamics studies in monsoon-arid transition zone : an example from Chotasigri glacier, Himachal-Himalaya, India. Curr Sci 68:936-944

Dyurgerov MB and Meier MF (2005) Glaciers and the changing earth systems: a 2004 snapshot. Boulder, CO, Institute of Arctic and Alpine Research. Occasional paper 58

Ganjoo RK, Koul MN (2009) Is the Siachen glacier melting? Curr Sci 97(3):309-310

Giorgi F, Hurrell JW, Marinucci MR, Beniston M (1997) Elevation signals in surface climate change: a model study. J Clim 10:288-296

Gurung DR, Kulkarni AV, Giriraj A, Aung KS, Shrestha B, Srinivasn J (2011) Changes in seasonal snow cover in Hindu Kush Himalayan region. The Cryosphere Discussion 5:755-777

Hewitt K (2005) The Karakoram Anomaly? Glacier Expansion and the 'Elevation Effect,' Karakoram Himalaya Mountain Research and Development 25(4):332-340, 2005. doi:https://doi.org/10.1659/ 0276-4741(2005)025\%5b0332:TKAGEA\%5d2.0.CO;2

Hoaglin, D.C., F. Mosteller and J.W. Tukey, 1983. Understanding robust and exploratory data analysis, Wiley

Houghton JT, Ding Y, Griggs DJ, Noguer M, van der Linden PJ, Dai X, Maskel K, Johnson CA (2001) Climate change 2001: the scientific basis. In: Contribution of working group 1 to the third assessment report of intergovernmental panel on climate change. Cambridge University Press, Cambridge etc.

Immerzeel WW, Droogers P, Jong SMD, Bierkens MFP (2009) Large scale monitoring of snow cover and runoff simulation in Himalayan river basins using remote sensing. Remote Sens Environ 113:40-49

Immerzeel WW, Van Beek LPH, Bierkens MFP (2010) Climate change will affect the Asian water towers. Science 328:1382-1385

IPCC (2007) Climate change : the scientific basis. Cambridge University Press, Cambridge

Jhajharia D, Singh VP (2010) Trends in temperature, diurnal temperature range and sunshine duration in northeast India. Int J Climatol. https://doi.org/10.1002/joc2164

Kaul MK and Puri VMK (1999) Inventory of the Himalayan glacier: a contribution to the international hydrological Programme. In M. K. Kaul and V.M.K. Puri (Ed.), Geological Survey of India, 165 pp.

Kulkarni AV, Bahuguna IM, Rathore BP, Singh SK, Randhawa SS, Sood RK, Dhar S (2007) Glacial retreat in Himalaya using Indian remote sensing satellite data. Curr Sci 92(1):69-74
Kulkarni AV, Rathore BP, Alex S (2004) Monitoring of glacial mass balance in the Baspa basin using accumulation area ratio method. Curr Sci 86(1):185-190

Kumar K, Dumka RK, Miral MS, Satyal GS, Pant M (2008) Estimation of retreat rate of Gangotri glacier using rapid static and kinematic GPS survey. Curr Sci 94(2):258-262

Liu XN, Sun AJ (1995) An inhomogeneity test study of annual precipitation series (in Chinese with English abstract). Meteorol Monogr 21:3-6

Menon S, Koch D, Beig G, Sahu S, Fasullo J, Orlikowski D (2010) Black carbon aerosols and the third polar ice cap. Atmos Chem Phys 10: 4559-4571

Mohanty UC, Dimri AP (2004) Location specific prediction of probability of occurrence and quantity of precipitation over western Himalaya. Weather Forecast 19(3):520-533

Mool PK, Bajracharya SR, Joshi SP (2001a) Inventory of glaciers, glacial lakes and glacial lake outburst floods: monitoring and early warning systems in the Hindu Kush Himalaya region, Nepal. Kathmandu, International Centre for Integrated Mountain Developments

Mool PK, Wangda D, Bajracharya SR, Kuzang K, Gurung DR, Joshi SP (2001b) Inventory of glaciers, glacial lakes and glacial lake outburst floods: monitoring and early warning systems in the Hindu Kush Himalaya region, Bhutan. Kathmandu, International Centre for Integrated Mountain Developments

Naithani AK, Nainwal HC, Sati KK, Prasad C (2001) Geomorphological evidences of retreat of the Gangotri glacier and its characteristics. Curr Sci 80(1):87-94

Nie Y, Zhang Y, Liu L, Zhang J (2010) Glacial changes in the vicinity of Mt Qomolangma (Everest), central high Himalayas since 1976. J Geoge Sci 20(5):667-686

Press WH, Flannery BP, Teukolsky SA, Vetterling WT (1986) Numerical recipes : the art of scientific computing. Cambridge University Press

Ramanathan V, Ramana MV, Roberts G, Kim D, Corrigan C, Chung C, Winker D (2007) Warming trends in Asia amplified by brown cloud solar absorption. Nature 448:575-578

Sateesh SK, Krishnamoorthy K, Sureshbabu S, Vinoj V, Dutt CBS (2008) Climate implications of large warming by elevated aerosol over India. Geophys Res Lett 35(L19809). https://doi.org/10.1029/ 2008GL034944

Shrestha AB, Wake CP, Mayewski PA, Dibb JE (1999) Maximum temperature trends in the Himalaya and its vicinity: An analysis based on temperature records from Nepal for the period 1971-94. J Clim 12:2775-2767

Shrestha AB, Wake CP, Dibb JE, Mayewski PA (2000) Precipitation fluctuations in the Nepal Himalaya and its vicinity and relationship with some large scale climatological parameters. Int J Climatol 20:317-327

Solomon S, Qin D, Manning M, Chen Z, Marquis M, Averyt KB, Tignor M, Miller HL (2007) Climate change 2007: the physical science basis. In: Contribution of working group 1 to the fourth assessment report of intergovernmental panel on climate change. Cambridge University Press, Cambridge etc.

Upadhyay R (2009) The melting of the Siachen glacier. Curr Sci 96(5): 646-648

Vernekar AD, Zhou J, Shukla J (1995) The effect of Eurasian snow cover on the Indian monsoon. J Clim 8:248-266

Vincent LA (1998) A technique for the identification of inhomogeneities in Canadian temperature series. J Clim 11:1094-1104

Wagnon P, Linda A, Arnaud Y, Kumar R, Sharma P, Vincent C, Pottakal JG, Berthier E, Ramanathan A, Hasnain SI, Chevallier P (2007) Four year mass balance on Chotasigri glacier, Himachal Pradesh, India, a new benchmark glacier in the western Himalaya. J Glaciol 53(183):603-611

Wilks DS (1995) Statistical methods in the atmospheric sciences. US, Academic Press 